\title{
Fotografia: câmara clara ou caixa preta?
}

Rafael Alonso

UFSC

\section{Resumo}

A proposta central do ensaio é ler A câmara clara (1980), de Roland Barthes, em contraposição à Filosofia da caixa preta (1983), de Vilém Flusser. Este encontro, porém, ocorre apenas na parte final do texto. Antes, este trabalho julgou interessante ler criticamente outros conhecidos ensaios sobre a fotografia, como os de Walter Benjamin, Siegfried Kracauer e Susan Sontag. Também é conferida atenção especial a O imaginário (1940), de Jean-Paul Sartre, obra à qual Barthes dedica seu livro sobre a fotografia. O objetivo deste ensaio, no geral, é refletir sobre como os teóricos acima lidam com o referente, bem como com um possível "fora" da imagem. O caminho escolhido tende a anular a problemática separação entre o "mundo real" e o "mundo da imagem".

Palavras-chave: câmara clara; caixa preta; fotografia; Barthes, Flusser.

\section{Resumen}

La propuesta central del ensayo es leer A câmara clara (1980), de Roland Barthes, en contraposición a Filosofia da caixa preta (1983), de Vilém Flusser. Este encuentro, sin embargo, se produce sólo en la parte final del texto. Antes, este trabajo juzgó interessante leer otros ensayos conocidos sobre el tema, como los de Walter Benjamin, Siegfried Kracauer e Susan Sontag. También se presta especial atención a O imaginário (1940), de Jean-Paul Sartre, a quien Barthes dedica su libro acerca de la fotografía. El propósito del ensayo, en general, es reflexionar sobre cómo los teóricos citados piensan el referente, así como un possible "afuera" de la imagen. El camino elegido tiende a anular la problemática separación entre el "mundo real” y el "mundo de la imagen".

Palabras clave: câmara clara; caixa preta; fotografía; Barthes; Flusser. 


\section{Uma fotografia da mãe, ou do porquê de a câmara ser clara}

\author{
1. Por exemplo: "Nessa \\ pesquisa sobre a Fotografia, a \\ fenomenologia emprestava-me, \\ então, um pouco de seu projeto \\ e um pouco de sua linguagem". \\ BARTHES, Roland. A câmara \\ clara, 1984, p. 37. \\ 2. Ibidem, p. 109. \\ 3. Ibidem, p. 110.
}

4. Ibidem, p. 19.
6. Ibidem, p. 46.

5. Ibidem, p. 48.
Não é possível afirmar que Roland Barthes elabore uma teoria da fotografia, mesmo que tenha dedicado um livro, o último livro que escreve antes de morrer, ao tema: A câmara clara, finalizado em 1979 e publicado no ano seguinte. Apoiado no método fenomenológico, algo que confessa aqui e ali ${ }^{1}$, Barthes se esforça por definir "algo como uma essência da Fotografia". E o faz a partir de apenas uma imagem, a única cuja existência ele consegue afirmar a si próprio com segurança. A única imagem que verdadeiramente o toca: uma fotografia da mãe quando pequena. Por uma razão até duvidosa - "nela, para vocês, não há nenhuma ferida"’, Barthes veda ao leitor o acesso ao retrato.

Ele, assim, não pretende teorizar sobre a fotografia, mas, por meio de um método empírico, elucidar os motivos que tornam aquela imagem marcante. É evidente que ao longo do ensaio ele exibe um número grande de imagens. Mas não as reúne para compor um conjunto coeso a partir do qual pudesse elaborar uma ideia geral - "nada a ver com um corpus: somente alguns corpos"4 -, mas para que essas imagens esclareçam o leitor daquilo que o leva a gostar mais de umas fotografias, e menos de outras. Mais especificamente, para ser fiel aos termos empregados, as imagens the servem para definir, e diferenciar, o que entende por studium e punctum.

$\mathrm{O}$ primeiro tende a ressaltar o aspecto geral e evidente. $\mathrm{Na}$ linha de Barthes, não é descabido dizer que o fotojornalismo caminha na direção do studium. O objetivo do fotojornalista, segundo ele, é o de levar ao espectador, o spectator, um significado claro e distinto. Exemplo: se fotografo uma guerra que julgo desigual, uma imagem que exibisse corpos ao chão, sob o olhar arrogante de um soldado das Forças Armadas da potência bélica em vantagem, daria um excelente studium. De modo geral, essas imagens têm a pretensão de transmitir uma "mensagem" ao observador, em geral em tom de denúncia política. Neste caso, é como se o espectador devesse enxergar exatamente aquilo que o fotográfico se dispôs a registrar. Natural, assim, que o crítico que com tanta ênfase anunciou a "morte do autor" desconfiasse desse tipo de imagem. Em resumo, o studium está do lado da cultura 5 .

Se o studium posiciona-se mais ao lado do fotógrafo, o punctum assenta-se ao lado do espectador. Trata-se do detalhe fugidio, que pode ou não passar despercebido. Pessoal e intransferível, é a "picada, pequeno buraco, pequena mancha, pequeno corte - e também lance de dados" " que punge o espectador e o lança na direção da fotografia. Ao contrário do studium, que exige quase que um comportamento ético, o punctum "pode ser 
mal-educado" ". No exemplo citado acima, é possível, sob esta perspectiva, que eu ignore tanto os corpos estendidos no chão quanto a pose do soldado e me atenha a uma passante, para lembrar Baudelaire, que caminha despreocupada ao "fundo". Também é comum que o punctum não se adeque às intenções do fotógrafo e deva seu registro a um acaso espaço-temporal: alguém, ou algo, passou diante da objetiva, ou lá já se encontrava, no momento do disparo, fato que só veio a ser percebido pelo disparador depois que visualizou a imagem impressa, ou na tela.

Após a leitura das "análises" - melhor seria dizer dos comentários - das várias imagens expostas na obra, o que poderíamos considerar, na opinião de Barthes, como a "essência da fotografia"? Em que ponto é possível encontrar a "natureza" da imagem fotográfica? A resposta surge da própria definição de punctum, pois é a partir desta picada que, num segundo movimento, o espectador é lançado para fora da imagem. O punctum permite sondar a vida que o retratado de fato viveu. Ele cria um "campo cego" 8 . Esse processo, na medida em que apela à vivência de quem olha para a imagem, faz lembrar que o retratado já morreu ou vai morrer, assim como o observador, cedo ou tarde, irá morrer. É no punctum que Barthes sente palpitar, nas fotografias que o tocam, mas em especial no retrato da mãe, o inexorável “isso foi” (ça-a-été).

O elemento instituinte da fotografia, para Barthes, é a inegável existência daquilo que vemos na imagem, ou, em linguagem semiótica, do referente. Se o "objeto" fotografia tem pouco ou nenhum valor, afinal, em fotografia, o que conta é a informação, o elemento imaterial, Barthes conclui que esta se define pelo referente, "ordem fundadora da fotografia" . Não vemos uma escultura como vemos uma fotografia. Melhor dito: não vemos uma fotografia, vemos o que ela nos dá a ver. "Em suma, referente adere"10. Ou ainda: "A foto é literalmente uma emanação do referente"11. A marca da fotografia é a capacidade de reproduzir mecanicamente algo que não se repetirá no plano existencial. A referencialidade da imagem fotográfica pode ser captada, segundo Barthes, através de dois gestos: o daquele que dispara a máquina e o daquele que posa para a máquina.

Sobre o segundo, vale lembrar que Barthes também considera a pose um aspecto definidor da fotografia ${ }^{12}$. Não tanto o posar caricato e artificial dos que se colocam à frente da câmara, mas o pôr-se diante de - da objetiva. Um retrato, por exemplo, atesta que, numa data passada, distante ou não, uma figura humana, viva, posou diante da câmera. Em relação ao gesto do disparador da câmera, ele aponta que "a vidência do fotógrafo não consiste em 'ver', mas em estar lá"13. Desta forma, não está tanto em jogo o "objeto" escolhido pelo fotógrafo para ser registrado, mas o fato do registro exigir a presença física in loco
7. Ibidem, p. 71.

8. Ibidem, p. 86 .

9. Ibidem, p. 115.

10. Ibidem, p. 16.

11. Ibidem, p. 121.

12. Ibidem, p. 117.

13. Ibidem, p. 76. 
14. Poderíamos sondar que acréscimos ou críticas sofreria esse aspecto do pensamento de Barthes levando em conta o fato de, hoje em dia, o "tirar" fotografias não exigir a presença física do fotógrafo no local.

No caso das imagens captadas por drones (mini-helicópteros capazes de filmar, fazer fotos, entregar pizzas e lançar bombas), o próprio elemento humano é dispensável no processo. Por outro lado, o que certamente corrobora a leitura de Barthes são as coberturas televisivas de guerra. Tratamse, na maioria dos casos, de coberturas insossas, nas quais o repórter limita-se a reproduzir informações emitidas pelas fontes oficiais ou pelas agências de notícias mais renomadas. O que importa, nesse caso, é o repórter "estar lá", posar diante do vídeo trajando colete à prova de bala e capacete, dar a entender que se sujeita ao perigo e que arrisca a própria vida para informar o telespectador. É a figura do jornalista-heroi.

15. BARTHES, Roland. $A$ câmara clara, 1984, p. 123.

16. Ibidem, p. 99. daquele que manuseia a câmara ${ }^{14}$. A fotografia não restitui o que é abolido nem remonta o passado, ela atesta que algo existiu ${ }^{15}$.

Sob esse ponto de vista, não é irrelevante pensar no fato de a imagem que mais punge Barthes, quem sabe a única que lhe punctua, ser a de um retrato da mãe ainda criança. À parte o estudo psicanalítico que poderia ser feito, mas que aqui será deixado de lado, pelo fato de a imagem que mais lhe impacta ser a da mãe, convém ressaltar que se trata de uma mãe que, por assim dizer, ele não conheceu. O punctum em Barthes parte de uma imagem da mãe à qual ele não estava acostumado. "Eu a reconhecia diferencialmente, não essencialmente"16.

Afora a leitura emocionada que ele faz do retrato, dizendo poder reconhecer os principais traços da personalidade da mãe nesse registro da infância, não é absurdo admitir que Barthes pode "ver" a mãe apenas porque a foto em questão se encontrava na caixa que guardava os pertences do ser amado. Barthes, quando olha para a imagem da criança, já sabe que aquela que "está lá" é sua mãe. Assim, uma crítica com pitadas racionais poderia ser direcionada ao teórico: ele sabia de antemão que a criança retratada era sua mãe e, neste sentido, uma escolha que em tese se deu por acaso, resultado de um punctum que picou aquele que vasculhava a caixa, poderia, em verdade, ser o resultado de uma escolha conveniente que reforçasse suas divagações sobre a fotografia. Reconhecer a mãe morta numa imagem da tenra infância é o coroamento perfeito da ideia de punctum e da presença espantosa do "isso foi" que perpassa toda "Câmara Clara". Proposital ou afetiva, a escolha é coerente e permite reter o elemento que, para Barthes, é fundamental na fotografia: o tempo.

\section{Uma fotografia da avó, ou da crítica ao historicismo}

Se o punctum em Barthes surge a partir de uma imagem da mãe ainda criança, o que motiva o ensaio "A fotografia", de Siegfried Kracauer, publicado em 1927, é uma fotografia da avó (adulta). Em princípio, os netos, entre eles Kracauer, encontram apenas motivos para zombar, tanto da avó quanto do aspecto démodé de toda composição. A pose já está superada, o coque é defasado, a cintura alta caiu em desuso, etc. Mas, assim como Barthes, ele percebe que toda fotografia, independentemente daquilo que dá a ver, um parente próximo ou uma luminária de cristal, carrega consigo um elemento temporal, um traço de tempo, "a configuração espacial de um instante" ${ }^{17}$ que atesta

uma existência.
17. KRACAUER, Siegfried. "A fotografia", 2009, p. 73. 
Kracauer afirma que a avó, num primeiro momento, poderia ser comparada a um manequim, ou seja, apenas um suporte material que serviria para fazer lembrar os costumes típicos e o vestuário da metade do século XIX. Em linguagem historicista - a tradução ao português traz o termo "historista" -, a fotografia se resumiria a um mero registro histórico, um registro de época. Neste aspecto em particular, vale ressaltar que Kracauer critica duramente o pensamento historiográfico de raiz positivista, na medida em que este, com o advento da fotografia, acreditava poder reconstituir linearmente a história, acrescentando à espacialidade referencial da fotografia uma temporalidade infalível. Em poucas palavras, a fotografia funcionaria, sob esse viés, como um documento comprovador, porque em teoria objetivo, de teorias progressistas da história ${ }^{18}$.

A expectativa de Kracauer, ao contrário, era que o meio técnico permitisse a desativação da história enquanto continuidade unívoca. Ao longo do ensaio, ele faz uma diferenciação significativa entre símbolo e alegoria - sem citar seu amigo Walter Benjamin. Enquanto o primeiro permanece preso ao mito e mantém o homem veiculado à natureza, a segunda permite a distância crítica e dá ao homem a condição de enxergar o mundo sob ponto de vista ainda inobservado. O pensamento simbólico crê não haver ruído entre o mundo e as representações que dele se faz. Ou confia que o mundo pode ser captado sem erro a partir destas mesmas representações. Já o pensamento alegórico sabe, de partida, que o conhecimento só acontece por linhas tortas - só dispomos de métodos equívocos. Para Kracauer, a técnica possibilita ao homem desnaturalizar o olhar e, consequentemente, enriquecer as formas pelas quais entra em contato com o mundo ${ }^{19}$, ou ainda, "suprimir toda relação habitual entre os elementos naturais" ${ }^{\prime 20}$.

Num processo como esse, a memória é fundamental. Kracauer assinala que, ao contrário da fotografia, que tem como marca a irrefutabilidade do referente, a memória é falha. Mas, se perde em objetividade, ganha em potência significativa. Assim, a equivocidade da memória, associada à univocidade da fotografia, poderia gerar uma forma de conhecimento que escapasse do historicismo. Seria quase como incluir pitadas próprias ("subjetivas"), ainda que advindas de um locus muitas vezes fincado no inconsciente e no involuntário, num estrato objetivo previamente dado. A Recherche, de Proust, que não deixou de empolgar Kracauer, caminha próxima desta trilha.

Esse mesmo movimento é o que parece animar o olhar de Barthes na direção da fotografia da mãe, bem como o de Kracauer quando se depara com a imagem da avó, igualmente morta:
18. "Paradoxo: o mesmo século inventou a História e a Fotografia". BARTHES, Roland. A câmara clara, 1984, p. 139.

19. Em momento praticamente contemporâneo, os formalistas russos falavam em desautomatização da percepção por meio do estranhamento que a linguagem poética poderia provocar.

20. KRACAUER, Siegfried. "A fotografia", 2009, p. 79. A publicação, em 1960, de Theory of film: the redemption of physical reality, aprofundaria esse ponto de vista.

A fotografia torna-se um fantasma porque a boneca vestida com os trajes de época foi viva uma vez. Através da 

enganadores foram incluídos na vida como acessórios evidentes. [...] Quando a avó estava diante da objetiva, estava por um segundo no contínuo espacial que se apresentava à objetiva. No lugar da avó, é aquele instante que foi eternizado. Quem observa velhas fotografias é tomado por calafrios, já que estas não tornam evidente o conhecimento do original, mas a configuração espacial de um instante; não é o ser humano que emerge de sua fotografia, mas a soma do que se pode extrair dele. Soma que o aniquila enquanto o reproduz: o ser humano não existiria se coincidisse com a fotografia. ${ }^{21}$

Uma história que coincidisse com uma determinada imagem seria totalitária. A objetividade da fotografia, como um vestígio, atesta uma existência, mas não reconstitui um momento passado.

\section{Uma dedicatória, ou do estranhamento desta}

22. SARTRE, Jean-Paul. O imaginário, 1996, p. 19.

23. Ibidem, p. 24.
Hoje em dia, pode soar démodé. Mas, em outros tempos, era comum que as pessoas presenteassem umas às outras com fotografias. No reverso do papel, escrevia-se uma dedicatória, acompanhada da data em que a foto foi tirada. Pois bem, Barthes dedica A Câmara Clara a Jean-Paul Sartre. Mas não apenas a seu conterrâneo, mas a uma obra específica deste: $O$ imaginário, de 1940. Uma visita a este trabalho pode, portanto, ser produtiva.

De partida, é preciso dizer que Sartre se ocupa, essencialmente, do espaço do imaginário. Desta forma, sua atenção está voltada, acima de tudo, ao que chama de "imagem mental", relegando a imagem do retrato - pintura e fotografia - a subcapítulos do livro. A imagem, para Sartre, separa-se radicalmente da percepção. A segunda está ligada aos sentidos, ao contato direto com o mundo, à vida prática. Já a primeira é sempre uma tentativa secundária da consciência de refazer mental e sinteticamente determinado objeto. A imagem, assim, "é um certo modo que o objeto tem de aparecer à consciência ou, se preferirmos, um certo modo que a consciência tem de se dar um objeto"22.

Para Sartre, a consciência é que preside a formação das imagens mentais - nada mais avesso ao punctum barthesiano. É por isso que "minha percepção pode enganar-se, não minha imagem" 23 . Se a percepção permite um aprendizado, um conhecer, ainda que lento, a imagem oferece-me o objeto imediatamente. Mas, como se trata de um trabalho consciente, ou seja, faço aparecer em minha mente um objeto que já conheço 
através da percepção, a imagem não suporta o conhecimento e nem o saber. "Em suma, o desejo é um esforço cego para possuir no plano representativo o que já tenho no plano afetivo [...] poderíamos dizer que é impossível encontrar na imagem algo mais do que aquilo que colocamos; dito de outra forma, a imagem não ensina nada"24.

Sartre dá o exemplo de alguém que está sentado no sofá de sua casa e resolve se divertir. Para isso, começa a imaginar um cubo e, mentalmente, faz esse cubo girar, conseguindo, em razão deste trabalho imaginativo, visualizar as suas seis faces. No entanto, o crítico é taxativo: ao final da operação não se terá avançado nada, e o aprendizado será nulo. Nesta linha, ele tece uma separação bastante problemática entre pensamento e imagem: se o primeiro é uma consciência que afirma certas características dos objetos, sem realizá-los, a segunda é "simbólica" 25 na medida em que visa produzir os objetos. O que Sartre põe em questão é a eficácia do pensamento imaginativo.

Não parece condenável a afirmação de Sartre de que a imagem (mental) tem por característica principal a concreção. Produzir imagens é uma forma de produzir o mundo, ainda que simbolicamente. A implicância sartreana refere-se ao fato de que, em sua opinião, a consciência imaginante não ser materialmente realizável. É por isso que ele critica tão intensamente o aspecto simbólico do imaginário. Para Sartre, ao menos o Sartre desta obra de 1940, não há conhecimento possível que brote da imaginação. O conhecimento relevante deve partir da percepção.

É essa implicância, ou essa desconfiança, que faz Sartre, em nota de rodapé, "rejeitar inteiramente a existência de um inconsciente" ${ }^{\text {, }}$, que o leva igualmente a intitular um de seus subcapítulos como "patologia da imaginação" e o obriga a, por meio de avaliações bastante duvidosas, dissociar o sonho da vigília. Há em Sartre um ímpeto racional que tende a barrar o impulso e a potência imaginativos. Se acredito na "realidade" de um sonho, por exemplo, a consciência desperta deve ser imediatamente acionada. O mesmo vale para o caso de um leitor de romance que resolva mergulhar na narrativa de modo profundo ou se coloque quase existencialmente na posição do protagonista. "O cogito cartesiano conserva seus direitos mesmo entre os psicopatas"

A leitura de $O$ imaginário, tendo Barthes no horizonte, conduz a perguntas inevitáveis: por que, afinal, Barthes dedica justamente $A$ Câmara clara a este livro de Sartre? As teses lançadas por um não são diametralmente opostas às elaboradas pelo outro? Há algo mais contrário ao racionalismo sartreano do que a ideia de punctum de Barthes? O que faz Barthes não é tornar viva e "presente" a própria mãe por meio de uma imagem? Por fim: o que, afinal, poderia aproximar trabalhos em princípio tão
24. Ibidem, p. 101, 139.

25. Ibidem, p. 132.

26. Ibidem, p. 36

27. Ibidem, p. 196. 
28. Ibidem, p. 36 .

29. Ibidem, p. 28.

30. "Eis aqui portanto, finalmente, a definição da imagem, de toda imagem: a imagem é aquilo de que sou excluído". BARTHES, Roland. "As imagens", 2003, p. 211.

31. SONTAG, Susan. Ensaios sobre fotografia, 1981, p. 69.

32. "Precisamente por lapidar e cristalizar determinado instante, toda fotografia testemunha a dissolução inexorável do tempo". Ibidem, p. 15. heterogêneos, aproximação que o leitor se vê forçado a fazer na medida em que um dos ensaios está dedicado ao outro?

Em primeiro lugar, é preciso aclarar que para Sartre as imagens mentais às "caricaturas, fotos são, portanto, espécies de um mesmo gênero" 28 . Ou seja, embora reflita principalmente sobre o que chama de imagem mental, ele não exclui da mesma análise as imagens fotográficas. Em ambos os casos trata-se, segundo o crítico, de tornar presente algo que está ausente. Uma imagem é sempre um representante de algo com o qual não se pode contar. "Por mais viva, tocante, forte que uma imagem seja, ela dá seu objeto como não sendo" 29 . No meio de pensamentos aparentemente diversos, um fio comum atravessa a teia: toda a imagem traz o peso de uma falta ${ }^{30}$. No entanto, a ausência, em Barthes, é punctum; em Sartre, buraco insuficiente que deve ser preenchido pela percepção.

\section{Um luto, ou da lamentação pela morte do referente}

Uma dicotomia entre mundo e imagem é aberta. Para críticos com tendências conservadoras, como é o caso de Sartre, essa dicotomia é vista com maus olhos. É preciso que a consciência desperta coloque, em recipientes separados, aquilo que cabe à percepção, ao "mundo real", e aquilo que cabe ao espaço do imaginário, à imagem. Embora de maneira menos evidente, essa é a perspectiva que norteia os engajados Ensaios sobre fotografia publicados por Susan Sontag na década de 1970.

Sontag não discorda de Barthes no que se refere ao fato de a fotografia captar, mais do que uma figura humana ou um objeto do cotidiano, uma passagem do tempo. É como se a figura retratada servisse apenas de pretexto, de suporte, para a presentificação de uma duração. "Ver uma velha fotografia nossa, de alguém que conhecemos ou de uma pessoa célebre e muito fotografada é perceber sobretudo como eu (ela, ele) era mais jovem naquele tempo. A fotografia é o inventário da mortalidade" 31 . Também em Sontag, a fotografia afirma a passagem inexorável do tempo: todos morreremos ${ }^{32}$.

Mas a preocupação principal dos ensaios de Sontag aproxima-se mais das ponderações de Sartre do que das de Barthes. O termo ativista, muitas vezes empregado para definir a norte-americana, é redutor, mas aponta numa direção que não pode ser ignorada. Para Sontag, à parte os elementos técnicos da fotografia, ou seja, por mais que esta capte a "realidade", ela não deixa de ser um instrumento que serve à interpretação do 
mundo ${ }^{33}$. E tal interpretação nunca é gratuita: está à serviço de uma ideologia. Segundo Barthes, a fotografia começa por registrar aquilo que é notável para depois tornar notável aquilo que registra. De acordo com Sontag, o que constitui um acontecimento que mereça ser registrado é a ideologia. Conceituar com mais precisão o termo ideologia demandaria algumas páginas. De momento, o que se retém é que, na opinião da ensaísta, "atrás" de toda fotografia esconde-se uma posição política.

O problema deste viés analítico é que demanda a confiança na existência de uma realidade que deve ser retratada com fidelidade. A fotografia, para cumprir o seu papel, deve reproduzir fielmente a realidade. Duas questões se colocam aqui: 1. Há uma realidade objetiva que deva ser captada com fidelidade? 2. Cabe ao aparelho e, além disso, é o aparelho capaz de registrar fielmente essa dada realidade? A suspeita de Sontag é que a fotografia não dá conta de apreender a vida em todas as suas dimensões: "A vida não são detalhes significantes, iluminados por uma fração de segundo, fixados para sempre. A fotografia o é"34. A fixidez da fotografia não contém a fluidez da vida ${ }^{35}$.

Mais do que isso: pode falsificá-la. Para Sontag, uma pintura falsa, cuja autoria foi atribuída erradamente, falsifica a história da arte. Uma fotografia falsa, que se utiliza de retoques ou de adulterações técnicas, falsifica a realidade ${ }^{36}$. É compreensível a revolta de Didi-Huberman quando as quatro escassas imagens dos campos de concentração são modificadas tecnicamente, por exemplo, para levantar o seio de uma das confinadas. Isso é cri$\mathrm{me}^{37}$. Mas supor que a fotografia tende a falsificar a realidade é permanecer preso na dicotomia entre original e cópia que a própria técnica parece ter derrubado ${ }^{38}$. Para desespero de Sontag, no tempo em que escreve seus "Ensaios" as pessoas começam a procurar a "realidade" não mais no mundo, mas nas telas dos aparelhos. Ela lamenta o fato de um descontentamento em relação a essa suposta realidade levar as pessoas a considerarem real o que é dado pela imagem. "A noção primitiva acerca da eficácia da imagem pressupõe que essa possua a qualidade das coisas verdadeiras, mas nossa tendência é atribuir às coisas reais as qualidades de uma imagem" 39 .

A leitura de Sontag da fotografia não escapa do nó entre o que ela chama de "mundo fotografado" e "mundo real". No "mundo real", algo acontece agora e ninguém sabe o que vai acontecer no futuro. No "mundo fotografado", esse algo já aconteceu, e acontecerá sempre da mesma forma ${ }^{40}$. Parte daqui a crítica que Sontag faz ao surrealismo, e também, com reservas, a Benjamin: o trapeiro acha inútil entender o mundo e, por isso, coleciona-o.
33. Ibidem, p. 7.

34. Ibidem, p. 80.

35. "Quem intervém é incapaz de registrar; aquele que está registrando não pode intervir". Ibidem, p. 12.

36. Ibidem, p. 84.

\section{DIDI-HUBERMAN,}

Georges. Imágenes pese a todo, 2004.

38. "As belas-artes tradicionais apoiam-se na distinção entre o autêntico e o falso, o original e a cópia, entre o bom e o mau gosto; os meios de comunicação social confundem, quando não abolem pura e simplesmente, tais distinções". SONTAG, Susan. Ensaios sobre fotografia, 1981, p. 142.

39. Ibidem, p. 152.

40. Ibidem, p. 161. 


\section{Um olhar para a técnica, ou da precisão de Walter Benjamin}

41. BENJAMIN, Walter.

"Pequena história da fotografia", 1994, p. 94.

42. Ibidem, p. 100.

43. Ibidem, p. 104.
Mais do que nunca, torna-se necessário consultar o conhecido ensaio de Walter Benjamin "Pequena história da fotografia”, de 1931. Ainda no começo do século XX, Benjamin se dá conta de que o fundamental na fotografia não é a reprodução fidedigna da realidade - como se sabe, a reprodução técnica arrebenta com a aura -, mas o manejo técnico do aparelho. Em linha teórica semelhante à de Kracauer, ele advoga que não é uma realidade primeira e objetiva que cabe à câmara registrar, mas, em sentido diverso, o aparelho pode permitir ao homem vislumbrar uma dada realidade que antes lhe estava vedada, inclusive fisicamente. À fotografia está aberta a possibilidade de trazer à tona o "inconsciente ótico": "Características estruturais, tecidos celulares, com os quais operam a técnica e a medicina, tudo isso tem mais afinidades originais com a câmara que a paisagem impregnada de estados afetivos, ou o retrato que exprime a alma do modelo"41.

Portanto, o horizonte que a fotografia lançava ao olhar não era, para Benjamin, o da oportunidade de retratar a realidade fielmente. É por isso que, segundo o crítico, a chance de sucesso do retrato era a de não efetivar o vínculo entre a fotografia e a atualidade, algo que é feito diariamente por jornais e revistas ilustradas. Aqui, fazendo coro a Barthes, Sontag e Kracauer, Benjamin reforça que no retrato não vemos a reprodução fiel de um ser humano, mas um resquício do tempo que já passou, e que continua a passar.

De qualquer forma, o essencial na fotografia, na visão benjaminiana, é afirmado sem meias palavras: "No entanto o decisivo na fotografia continua sendo a relação entre o fotógrafo e sua técnica" ${ }^{42}$. O fundamental para quem extrai imagens da câmara não é, necessariamente, produzir imagens que correspondam àquilo que se deseja reproduzir. Isso, aliás, só faria reforçar as nossas visões habituais do mundo. Benjamin percebe que a fotografia, ao invés de falsificar a realidade, como postula Sontag, poderia permitir um contato mais complexo com essa mesma realidade.

Cada um de nós pode observar que uma imagem, uma escultura e principalmente um edifício são mais facilmente visíveis na fotografia que na realidade. A tentação é grande de atribuir a responsabilidade por esse fenômeno à decadência do gosto artístico ou ao fracasso dos nossos contemporâneos. Porém somos forçados a reconhecer que a concepção das grandes obras se modificou simultaneamente com o aperfeiçoamento das técnicas de reprodução. ${ }^{43}$ 
Uma pergunta se coloca: na medida em que se instala um processo de reversibilidade entre imagem e realidade, ou seja, conforme nos damos conta, com Benjamin, de que a reprodução técnica de grandes obras pode influenciar nossa própria concepção destas obras, ou ainda, a partir do momento que a reprodução técnica de uma obra compõe, de maneira inseparável, o próprio olhar que construímos sobre essa obra, é ainda possível separar, tão cartesianamente, a imagem da realidade? Ou ainda: se o modo como olhamos a chamada realidade passa tão intensamente pelas novas mídias técnicas, ou seja, nosso olhar é cada vez mais mediado, é possível ainda sustentar a existência pura de um "mundo real"?

Benjamin é bastante claro quando comenta esses pontos problemáticos, direta ou indiretamente, em "Pequena história da fotografia". No entanto, uma possível resposta às perguntas lançadas no parágrafo acima advém de uma citação de Brecht - e, quando pensamos em Benjamin, sabemos da importância que ele reservava às citações. Na passagem referida, Brecht chega à conclusão de que, cada vez mais, a simples reprodução da realidade diz pouco ou nada sobre a realidade. Assim, uma fotografia das fábricas Krupp ou AEG pouco nos informa sobre essas instituições, já que as relações humanas, reificadas no processo industrial capitalista, não se manifestam. "É preciso, pois, construir alguma coisa, algo de artificial, de fabricado"44. Para Benjamin, o surrealismo e o cinema russo foram iniciativas nesta direção.

\section{Uma inversão, ou do porquê de a caixa ser preta}

No final de seu ensaio, Benjamin lança a suspeita de que, no futuro, a parte mais essencial da fotografia será a legenda. Ele diz ainda que o analfabeto do futuro não será aquele que não sabe fazer fotografias, mas o fotógrafo que não sabe ler suas próprias imagens. Fica nítido, mais uma vez, a relevância que Benjamin atribuía ao jogo consciente entre fotógrafo e aparelho. Quem também falou sobre esse tema com bastante propriedade foi Vilém Flusser, especialmente em seu livro mais conhecido e que lhe deu projeção mundial: Filosofia da caixa preta, de 1983.

Flusser alerta para o perigo corrente de tomar as imagens técnicas como não-simbólicas. Assim, ao invés de lê-las, como imagens, tomamo-las como janelas do mundo. É preciso tomar as imagens técnicas a partir de sua especificidade. Elas diferem, por exemplo, do que Flusser chama de imagens tradicionais, 
45. FLUSSER, Vilém. Filosofia da caixa preta, 2011, p. 32-33.

46. Barthes afirma que a experiência de ser fotografado lembrava-lhe a morte. Ao longo do jogo de múltiplas intenções que envolvem a produção de um retrato, ele diz que não se sentia nem sujeito, nem objeto, mas um espectro. BARTHES, Roland. A câmara clara, 1984, p. 27. como a pintura ou o que está estampado nas paredes das cavernas. Ao contrário da magia pré-histórica, que tinha em mente o "mundo lá fora", as imagens técnicas visam modificar os nossos conceitos em relação ao mundo. Isso devido ao fato de que essas imagens sucedem, e não precedem, o pensamento conceitual que iniciou formalmente com a escrita linear ${ }^{45}$.

A dificuldade na leitura das imagens técnicas passa diretamente pela maneira como elas são produzidas. Nas imagens tradicionais, um elemento humano é decisivo. De acordo com Flusser, quem se dispõe a avaliar uma pintura poderá sondar inúmeros aspectos, mas talvez o principal deles seja o de vasculhar a cabeça daquele que a produziu. Entre o mundo objetivo e a pintura interpõe-se a figura humana do pintor. No caso das imagens técnicas, o funcionamento é diferente. Entre esse mesmo mundo objetivo e a fotografia, interpõem-se a figura humana do fotógrafo, mas também a instrumentalidade do aparelho. Assim, grande parte do processo que leva à produção de uma imagem técnica é desconhecido do observador.

Flusser recorda que o artesão, durante o trabalho, estava cercado por seus instrumentos. O operário industrial, por sua vez, é quem rodeia a máquina que lhe cabe manejar. No primeiro caso, o artesão é o ponto determinado, enquanto seus instrumentos são as variáveis. No segundo, o operário torna-se a variável da máquina. Já o fotógrafo que lida com seu aparelho não é nem constante, nem variável ${ }^{46}$. O fotógrafo encontra-se amalgamado ao aparelho. É por isso que, para Flusser, o fotógrafo consciente de seu ofício não trabalha em sentido estrito, mas joga com, e contra o aparelho: é homo ludens.

Nesse amálgama que envolve homem e aparelho, um pode sobressair sobre o outro. É isso que definirá o desfecho do jogo. Em tese, aponta Flusser, o fotógrafo pode extrair do aparelho apenas as fotografias virtualmente realizáveis no programa. Ele está limitado a tirar somente as fotografias tiráveis. Mas, para sorte do fotógrafo, o programa do aparelho apresenta uma infinidade de virtualidades, sendo impossível, a ele, "zerar" o programa, como os adolescentes costumam falar dos jogos de seus videogames. As possibilidades do programa ultrapassam as possibilidades do fotógrafo. Desta forma, cabe a este último sacar imagens pouco previstas e previsíveis, explorar ao máximo as potencialidades do aparelho, ou, em linguagem cibernética, informar o mundo - fugir da entropia, produzir informações não redundantes. Embora não domine o input, o fotógrafo controla o output.

A definição flusseriana de caixa preta passa exatamente por aqui. Não é necessário conhecer a complexidade interna do aparelho, sua caixa preta, é preciso entender como ele funciona. "Um sistema assim tão complexo é jamais penetrado totalmente 
e pode chamar-se caixa preta. Não fosse o aparelho fotográfico caixa preta, de nada serviria ao jogo do fotógrafo: seria jogo infantil, monótono. A pretidão da caixa é seu desafio..." ${ }^{47}$.

Para que o jogo seja bem-sucedido cabe ao fotógrafo preencher a pretidão do aparelho com intenções humanas. Sendo assim, o fotógrafo não joga tanto com o aparelho, mas contra ele. Quer a todo custo esgotar-lhe as possibilidades. Caixa preta: jogar um jogo para o qual eu não estou completamente preparado. Flusser faz analogias recorrentes com o xadrez, esse jogo estruturalmente simples, mas funcionalmente complexo. Jogar é fácil, o difícil é jogar bem. E por mais estruturalmente pouco complexo que seja o xadrez - são 32 peças, 16 para cada jogador, e os movimentos de cada peça são claros e determinados -, inúmeras são as variáveis possíveis dentro do tabuleiro. É quase impossível que uma partida seja igual a outra.

Desta forma, é plausível dizer que Flusser radicaliza o pensamento benjaminiano de que se trata de um processo essencialmente técnico. Questões como a subjetividade, a afetividade, a fidelidade, a originalidade são colocadas em segundo plano. O que define a fotografia é a relação do aparelho com quem o manipula. Com Flusser, vê-se claramente que o fotógrafo não está tão ligado ao que Sontag chama de "mundo real" e ao que Sartre considera o espaço da percepção. Novas perguntas são lançadas à mesa: como pensar, assim, a dicotomia esboçada anteriormente, principalmente a partir dos dois críticos supracitados, entre a imagem, de um lado, e o mundo real, do outro? Se o jogo do fotógrafo é contra o aparelho, se ele quer esgotar-lhe as virtualidades e não, por outro lado, registrar o mundo deste ou daquele jeito, ainda há a necessidade desta divisão? Será que, hoje, mais do que antes, nossa percepção já não esteja completamente afetada pelas imagens técnicas? Se num gesto impossível excluíssemos de nosso cotidiano todos os meios técnicos de reprodução da imagem, será que nos restaria, puro como o paraíso, a inteireza do "mundo real"? Mais radicalmente: é possível imaginar o nosso ser-no-mundo contemporâneo sem tais formas de mediação técnica? Será essa forma de participar do mundo uma estratégia falsificada e falsificadora? Vejamos o que pensa Flusser a esse respeito:

Na realidade, o fotógrafo procura estabelecer situações jamais existentes antes. Quando caça na taiga, não significa que esteja procurando por novas situações lá fora na taiga: mas sua busca são pretextos para novas situações no interior do aparelho. Situações que estão programadas sem terem ainda sido realizadas. Pouco vale a pergunta metafísica: as situações, antes de serem fotografadas, se encontram lá fora, no mundo, ou cá dentro, no aparelho? O gesto fotográfico desmente todo realismo e idealismo. As novas situações se tornarão reais quando aparecerem na fotografia.
47. FLUSSER, Vilém. Filosofia da caixa preta, 2011, p. 44. 
49. Ibidem, p. 75 .

50. BARTHES, Roland. $A$ câmara clara, 1984, p. 73.

51. Ibidem, p. 134.
Para Flusser, perguntas como "é fotografia arte?" ou "tal fotografia é politicamente engajada?" não fazem mais sentido. Ele reconhece, contudo, que a imagem técnica, enquanto meio de unificação da cultura, tem fracassado. No entanto, algumas distinções já estão desfeitas. Cabe ao fotógrafo fazer fotografias boas e belas, ou seja, estética e politicamente convincentes. Até porque, salienta Flusser, muitas vezes os próprios canais a que são destinadas as fotografias já respondem por si às perguntas sugeridas acima ${ }^{49}$. Nos primeiros parágrafos de "A fotografia", Kracauer afirma que as pessoas não se surpreendem com a imagem da diva na revista ilustrada pois já viram o original nas telas do cinema. Convém, agora, na parte final deste trabalho, voltar a Barthes e ver a que conclusões se pode chegar do cotejo entre a câmara clara e a caixa preta.

\section{Um encontro, ou do claro e do escuro}

Para Barthes, a fotografia superava-se a si mesma quando conseguia dar sua única prova de arte: "anular-se como medium", passando a ser não mais um signo, mas "a coisa mesma" ${ }^{50}$. Ele não estava alheio às discussões em torno à técnica fotográfica que se davam quando da escritura de $A$ Câmara Clara. O crítico nos recorda que a moda, à época, entre semiólogos e sociólogos, era assumir o ponto de vista da relatividade semântica: a fotografia, sempre codificada, não carrega nada de "real", apresentando-se como artifício. Da mesma forma, a fotografia não poderia ser admitida como analogon do mundo, traço comum que ela partilharia com todos os outros tipos de representação. A foto, como assinala Barthes, é uma emanação do real, ou seja, se aproveita de fótons e elétrons emitidos por um corpo, por meio de reflexos dos raios solares, e os imprime numa chapa através de um processo químico. Assim, a fotografia é não só um traço do tempo, como também um traço do real - caso se queira insistir com a separação entre mundo e imagem.

Fica claro que Barthes não ignorava o aspecto técnico da imagem fotográfica, apenas não o julgava uma possibilidade de leitura viável. Aliás, a despeito de seus códigos, ele sentenciava que "não posso ler uma foto" ${ }^{1}$. Nenhum elemento cultural 
poderia lhe fornecer ajuda para lidar com o sofrimento que experimenta ao contemplar a imagem da mãe. No entanto, ao mesmo tempo em que se inclui na categoria de "realista", sentenciando que a fotografia é uma imagem sem código, ele se defende: “[não considero] de modo algum a foto como uma 'cópia' do real - mas como uma emanação do real passado: uma magia, não uma arte. Perguntar se a fotografia é analógica ou codificada não é um bom caminho para análise". Segundo Barthes, na fotografia o poder de autentificação sobsome o de representação ${ }^{52}$.

Em A câmara clara, Barthes em nenhum momento se utiliza da expressão "caixa preta". No entanto, há uma passagem em que fala em "câmera obscura", no mesmo sentido em que Flusser emprega o termo que compõe o título de seu best-seller. Neste trecho, a diferença teórica entre ambos se torna nítida: "É equivocadamente que em virtude de sua origem técnica associam-na [a fotografia] à ideia de uma passagem obscura (camera obscura). O que se deveria dizer é camera lucida..." ${ }^{53}$.

Para Barthes, se a imagem fotográfica é codificada ou não, pouco importa. Em Flusser, o aspecto codificado da fotografia é o elemento central para quem anseia pensá-la criticamente. No prefácio de "Caixa preta", Flusser adverte que a fotografia lhe servirá de pretexto - o melhor modelo que encontrou para pensar todos os tipos de aparelhos que cercam o homem moderno. Segundo ele, é decisivo o fato de uma determinada imagem ser produzida por um aparelho. Isso nos leva a pensar não tanto em quem tirou determinada fotografia ou no que ela nos dá a ver, mas de que tipo de programa ela se aproveitou para ser produzida. A atenção abandona o "o quê" em nome do "como".

Barthes menciona que tomar a fotografia como emanação direta do real significa pensá-la como magia, e não como arte. Flusser, por sua vez, pontua que essa magia a que Barthes faz referência é magia de primeiro grau, ou seja, pleiteia a plena existência, na imagem, daquilo que ela retrata. É assim que os historiadores da arte ${ }^{54}$ leem grosseiramente as pinturas rupestres dos ditos "povos primitivos": pinto o bufão na parede da caverna a fim de melhor caçá-lo fora dela. Confio, assim, que o bufão da caverna é, mesmo que por alguns momentos, o bufão "real". "A foto me toca se a retiro de seu blablablá costumeiro: 'Técnica', 'Realidade', 'Reportagem', 'Arte', etc.: nada dizer, fechar os olhos, deixar o detalhe remontar sozinho a consciência afetiva" ${ }^{\prime 5}$.

Sob o viés flusseriano, portanto, a magia requerida por Barthes é de primeiro grau. Isso equivale a ver as imagens técnicas como janelas, e não como imagens. O detalhe, para Flusser, é que as imagens técnicas são magia de segundo grau, pois surgiram num momento histórico posterior ao do pensamento conceitual - resultado da escrita alfabética, marcada, em sua origem,
52. Ibidem, p. 132. Barthes assume o mesmo ponto de vista em relação à fotografía em anotações preparadas para um curso no Collège de France, que não foi ministrado em razão de sua morte, mas que se chamaria "Proust e a fotografia". As anotações datam do mesmo período da publicação de $A$ Câmara Clara. Nestes escritos, Barthes se limita a compilar uma série de fotografias dos principais personagens da Recherche, acrescentando apenas pequenas notas biográficas (legendas). Segundo Barthes, não havia o que dizer ou teorizar a respeito daquelas imagens, cabendo aos alunos fazer as relações que achassem convenientes. Novamente, prevalece a ideia de que as imagens devem "falar por si", estando a cada observador facultado o direito de deixar que as imagens os punctuem. "Intoxicado de quê? Do acúmulo desses rostos, desses olhares, dessas silhuetas, dessas roupas; de um sentimento amoroso por alguns; de nostalgia (eles morreram, eles estão todos mortos)". Idem. "Proust e a fotografia", 2005, p. 376.

53. Idem. A câmara clara, 1984, p. 156-157. No ensaio "Por onde começar?", de 1970, compilado em $O$ gran zero da escrita, Barthes se apropria de uma citação do linguista Isaac I. Revzin, extraído de Les principes de la theórie des modèles en linguistique em que aparece a expressão "caixa preta": "Em cada processo de elaboração da informação pode-se distinguir um certo conjunto A de sinais iniciais e um certo conjunto $\mathrm{B}$ de sinais finais observados. A tarefa de uma descrição científica consiste em explicar como se efetua a passagem de $\mathrm{A}$ a B, e quais são as ligações entre esses dois conjuntos (se os dois 
intermediários forem demasiado complexos e escaparem à observação, em cibernética, fala-se de caixa preta”. Ao que Barthes acrescenta: “ [...] é preciso em suma definir a passagem de um equilíbrio a outro, atravessar a "caixa preta". Idem. "Por onde começar?", 2004, p. 175.

54. Para uma visão diferente sobre o assunto, ver, de Georges Bataille: Lascaux o el nacimiento del arte (referência ao final).

55. BARTHES, Roland. $A$ câmara clara, 1984, p. 84-85.

56. FLUSSER, Vilém. Filosofia da caixa preta, 2011, p. 33.

57. Ibidem, p. 33.

58. BARTHES, Roland. $A$ câmara clara, 1984, p. 130.

59. Ainda que, no final de seu livro, Sartre pareça repensar a sua tese central: "Todo imaginário aparece 'sobre o fundo do mundo', mas, reciprocamente, toda apreensão do real como mundo implica uma ultrapassagem velada na direção do imaginário”. SARTRE, Jean-Paul. $O$ imaginário, 1996, p. 245. pela linearidade e iconoclastia. Ocorre que as imagens técnicas carregam em seu programa essa ideia "desmagicizante" 56 anterior, posto que, inicialmente, a escrita surgiu a fim de descrever as imagens. É por isso que elas não visam modificar o "mundo lá fora", pois está incluída em seu programa a informação de que as imagens não podem ser tomadas pela própria coisa. "É magia de segunda ordem: feitiço abstrato. Tal diferença pode ser formulada da seguinte maneira: a magia pré-histórica ritualiza determinados modelos, mitos. A magia atual ritualiza outro tipo de modelo: programas" ${ }^{57}$.

Se um dos objetivos de quem vive no mundo contemporâneo é evitar recair numa sociedade programada - nos termos de Flusser, é impedir que o fotógrafo se torne funcionário -, entender o modo de funcionamento dos programas torna-se fundamental. E isso não passa, necessariamente, pelo clareamento da caixa preta, ou seja, não é preciso que nos tornemos, do dia para noite, peritos em tecnologia. Passa por entender como os aparelhos operam e de que meios utilizamos para produzir imagens e fabricar o mundo através delas. Neste sentido, do ponto de vista teórico deste ensaio os postulados flusserianos sobre a fotografia podem gerar resultados criticamente mais interessantes, hoje em dia, do que as asseverações barthesianas.

Todavia, uma medida de cautela se faz necessária: Barthes não era um ingênuo. Ele não praticava magia de primeira ordem. O teórico reconhecia que a fotografia não era uma cópia fidedigna do mundo, mas uma emanação, um vestígio do tempo, um "isso foi”. Mesmo tendo em vista os elementos técnicos que intrinsecamente compõe a imagem fotográfica, a escolha é por ignorá-los. Como ele assinala, não lhe interessa uma Thesis, mas uma Physis ${ }^{58}$. Já foi dito, acima, que ignorar o aspecto técnico, atualmente, parece pecado mortal, tiro no pé.

Mas o fato de deixá-lo de lado propositalmente, conhecendo-O, coloca Barthes num patamar completamente diferente ao de Sontag e Sartre. Estes ainda apregoam a separação entre "mundo real" e "mundo das imagens", bem como lamentam a "perda" do referente. Ambos denunciam a incapacidade da fotografia de reproduzir fidedignamente o mundo em toda a sua completude. A fotografia, neste caso, é tomada sob o ponto de vista da ameaça, do perigo. Para Sontag, ela alimenta interesses ideológicos escusos e pode falsificar a realidade. Para Sartre, crer demasiado nas imagens é patológico - é sempre preciso separar o mundo consciente e racional do mundo da imaginação ${ }^{59}$. Ambos mostram-se presos à encruzilhada: ou intervenho no mundo ou produzo imagens. É evidente, porém, para todo iniciado de qualquer curso de ciências humanas, que há um conhecimento possível, literalmente imaginativo, que pode nascer das e com as imagens. Pense-se, apenas a título de exemplo, na tradição de pesquisa estabelecida a partir de Aby Warburg. 
Neste ponto, há uma aproximação viável entre Barthes e Flusser, pois o primeiro não lamenta, em momento algum, a incapacidade da imagem em tornar o mundo presente, mesmo que ao custo de uma dolorosa ausência. A mãe está morta e não vai ressuscitar. Sendo assim, a imagem é não apenas o mais efetivo, mas o único meio de que dispõe aquele que deseja sondar o passado. Sendo assim, o que Barthes propõe é uma confiança absoluta no referente. Ele defende uma fotografia louca em contraposição a uma fotografia sensata: "[...] louca, se esse realismo é absoluto e, se assim podemos dizer, original, fazendo voltar à consciência amorosa e assustada a própria letra do Tempo: movimento propriamente revulsivo, que inverte o curso da coisa e que eu chamarei, para encerrar, de êxtase fotográfico" ${ }^{00}$.

A loucura de Barthes pede que confiemos na referencialidade da imagem. A loucura de Flusser pede que desacreditemos do referente: o referente é apenas uma oportunidade para a realização de uma das virtualidades do aparelho. De todo jeito, sendo a câmara clara ou preta, um "fora da imagem" está fora de questão.
60. BARTHES, Roland. $A$ câmara clara, 1984, p. 175. 


\section{Referências}

BARTHES, Roland. A Câmara Clara: nota sobre a fotografia. Tradução de Júlio Castañon Guimarães. Rio de Janeiro: Nova Fronteira, 1984.

"As imagens". In: . Fragmentos de um discurso

amoroso. Tradução de Márcia Valéria Martinez de Aguiar. São Paulo: Martins Fontes, 2003, p. 211-213.

. "Proust e a fotografia: exame de um fundo de arquivos fotográficos pouco conhecido". In: . $A$

preparação do romance II: a obra como vontade: notas de curso no Collége de France 1979-1980. Tradução de Leyla Perrone-Moisés. São Paulo: Martins Fontes, 2005, p. 363-475.

. "Por onde começar?" In: O grau zero da escrita: seguido de novos ensaios críticos. Tradução de Mario Laranjeira. 2 ed. São Paulo: Martins Fontes, 2004, p. 173-186.

BATAILLE, Georges. Lascaux o el nacimiento del arte. Tradução de Axel Gasquet. Córdoba: Alción, 2003.

BENJAMIN, Walter. "Pequena história da fotografia". In: - Magia e técnica, arte e política: ensaios sobre literatura e história da cultura. Tradução de Sergio Paulo Rouanet. 7 ed. São Paulo: Brasiliense, 1994, p. 91-107.

DIDI-HUBERMAN, Georges. Imágenes pese a todo: memorial visual del Holocausto. Tradução de Mariana Miracle. Barcelona: Paidós, 2004.

FLUSSER, Vilém. Filosofia da caixa preta: ensaios para uma futura filosofia da fotografia. São Paulo: Annablume, 2011.

KRACAUER, Siegfried. "A fotografia”. In: O ornamento da massa. Tradução de Carlos E. J. Machado e Marlene Holzhausen. São Paulo: Cosac Naify, 2009, p. 63-80. Theory of film (The redemption of physical reality). USA, Princeton: Princeton U.P., 1997.

SARTRE, Jean-Paul. O imaginário: psicologia fenomenologica da imaginação. Tradução de Duda Machado. São Paulo: Ática, 1996.

SONTAG, Susan. Ensaios sobre fotografia. Tradução de Joaquim Paiva. Rio de Janeiro: Arbor, 1981. 